\title{
Monitoring and evaluation of lymphatic filariasis interventions: an improved PCR-based pool screening method for high throughput Wuchereria bancrofti detection using dried blood spots
}

\author{
Catherine Plichart ${ }^{*}$ and Aurore Lemoine
}

\begin{abstract}
Background: Effective diagnostic tools are necessary to monitor and evaluate interruption of Lymphatic Filariasis (LF) transmission. Accurate detection of Wuchereria bancrofti (Wb) microfilaria ( $\mathrm{mf}$ ) is essential to measure the impact of community treatment programmes. PCR-based assays are specific, highly sensitive tools allowing the detection of Wuchereria bancrofti DNA in human blood samples. However, current protocols describing the pool screening approach, use samples of less than $60 \mu$ l of blood, which limits the sensitivity of the pool-screen PCR assay. The purpose of this study was to improve the pool-screen PCR protocol to enhance its sensitivity and usefulness for population scale studies.
\end{abstract}

Findings: DNA extractions were performed with the DNeasy kit, the PCR with the Wb LDR primers and the SYBR-Green dye. Improvements of our pool-screen real-time PCR (qPCR) assay allowed the detection of as little as one Wb microfilaria diluted in a pool of at least 12 blood samples of $60 \mu$ each. Using this assay, mf burdens can be predicted using a standard curve derived from mf spiked dried blood samples. The sensitivity achieved is equivalent to the detection of a single LF positive individual carrying a $\mathrm{mf}$ burden as low as $18 \mathrm{mf} / \mathrm{ml}$, in a pool of blood samples from at least 12 individuals.

Conclusions: Due to its sensitivity, rapidity and cost-effectiveness, we suggest this GPCR pool-screening assay could be used as a diagnostic tool for population- scale filariasis elimination monitoring and evaluation.

Keywords: Lymphatic filariasis, Disease monitoring, Real-time PCR, Pool screen, Blood spots, French Polynesia

\section{Findings}

\section{Background}

The main goal of the Global Program to Eliminate Lymphatic Filariasis (GPELF) is to interrupt disease transmission by reducing microfilaremia prevalence in blood through mass drug administration (MDA) [1]. Diagnostic tools are required to assess the status of LF in countries that are now in the post-MDA surveillance phase or are still implementing preventive chemotherapy. The rapid immunochromatographic test (ICT), detecting filarial antigen, is the selected tool for deciding when to stop MDA [2] in areas where levels of infection have been reduced to a point where transmission is no

\footnotetext{
* Correspondence: cplichart@ilm.pf

Institut Louis Malardé, Papeete, Tahiti, French Polynesia
}

longer sustainable [3]. However, because antigenemia decreases more slowly than microfilaremia [4-6], the detection of $\mathrm{mf}$ in human blood populations of sentinel and spot-check sites remains an essential complementary test for assessing the impact of MDA [3,7-9]. Several methods are available for $\mathrm{mf}$ testing: the counting chamber method [10], the microscopic examination of capillary blood films (60- $\mu$ l thick) [11-14] or membrane filtration from one $\mathrm{ml}$ of venous blood [15]. Because these techniques can only be realized on individual samples, they are labour intensive and not adapted for monitoring residual $\mathrm{mf}$ prevalence rates in the community. As $\mathrm{mf}$ prevalence decreases through MDA, the pool screening approach becomes necessary and more cost effective [8]. PCR assays have been developed [16,17]

\section{C) Bïomed Central}

๑ 2013 Plichart and Lemoine; licensee BioMed Central Ltd. This is an Open Access article distributed under the terms of the Creative Commons Attribution License (http://creativecommons.org/licenses/by/2.0), which permits unrestricted use, distribution, and reproduction in any medium, provided the original work is properly cited. 
that are highly sensitive and specific for the detection of Wb DNA in individual human blood samples [18-20] as well as in mosquito vectors [21-25]. Conventional PCR and qPCR-based pool-screening methods, using pools of up to 10 blood samples of $10 \mu \mathrm{l}$ to $30 \mu \mathrm{l}$ each, have already been described [2,26-28]. However, they are less sensitive than the thick blood film method usually used [2], due to the low volume of blood analysed per patient. Thus, improving the pool-screening sensitivity of the qPCR assay by increasing the volume of blood tested would allow the broader implementation of this diagnostic tool.

The purpose of this study was to improve the DNA extraction protocol and qPCR assay to achieve the detection of a single $\mathrm{mf}$ in a pool of at least twelve $60-\mu \mathrm{l}$ blood samples.

\section{Human blood samples}

The assay was performed using capillary blood dried on filter paper as capillary blood is used to test microfilaremia in most countries endemic for LF. All procedures were carried out in the laboratory. All samples were acquired under protocols approved by the French Polynesia Ethics Committee with written informed consent obtained from all subjects. For each subject, $60 \mu \mathrm{l}$ of blood was loaded on 6 spots of a filter paper disk (TropBio, Townsville, Australia), dried and stored at $-20^{\circ} \mathrm{C}$ until use. Fifty-eight samples negative for filarial antigen (ICT and Og4C3) and for microfilariae (PCR and blood smear) were used for the assays. Samples containing one $\mathrm{mf}$ were obtained by very carefully spiking a single mf purified from the blood of a microfilaremic individual, onto the filter paper disk of a non-infected subject as identified above. Samples containing $3 \mathrm{mf}$ and $10 \mathrm{mf}$ were obtained similarly. Positive samples of approximately $100 \mathrm{mf}$ were prepared with $60 \mu \mathrm{l}$ of blood from an infected person whose microfilaremia was estimated at $1548 \mathrm{mf} / \mathrm{ml}$ by the filtration method. The six blood filter spots of each sample were processed.

\section{DNA purification}

DNA was extracted from the blood filter spots using the QIAGEN DNeasy kit (Qiagen, Hilden, Germany; Cat $\mathrm{N}^{\circ}$ 69504) following the manufacturer's instructions and increasing the volumes of reagents [Laney SJ, unpublished data]. Briefly, blood spots of a subject were placed in a $2 \mathrm{ml}$ microtube, covered with $270 \mu \mathrm{l}$ of ATL buffer, incubated at $85^{\circ} \mathrm{C}$ for ten minutes, then at $56^{\circ} \mathrm{C}$ for one hour after addition of $30 \mu \mathrm{l}$ of Proteinase K. Addition of $300 \mu \mathrm{l}$ of $\mathrm{Al}$ buffer to the digested suspension brought up the lysate volume to a total of $600 \mu \mathrm{l}$. From this step, we used two different protocols. First, the lysate was either heattreated $\left(100^{\circ} \mathrm{C}\right)$ or not, prior to the DNA purification. The aim of the heat treatment was to denature the genomic DNA to make the DNA target sequence more accessible to the primers. Second, individual lysates (total or fraction) or pooled lysates were processed in the subsequent DNA purification step. A volume of ethanol equivalent to half the volume of lysate sample was added before loading the mix onto a DNeasy spin column. Depending on the volume loaded, additional centrifugations were performed to pass all the solution through the column. After washing steps (twice with AW1 buffer, once with AW2 buffer), purified DNA was eluted in $200 \mu \mathrm{l}$ of AE buffer.

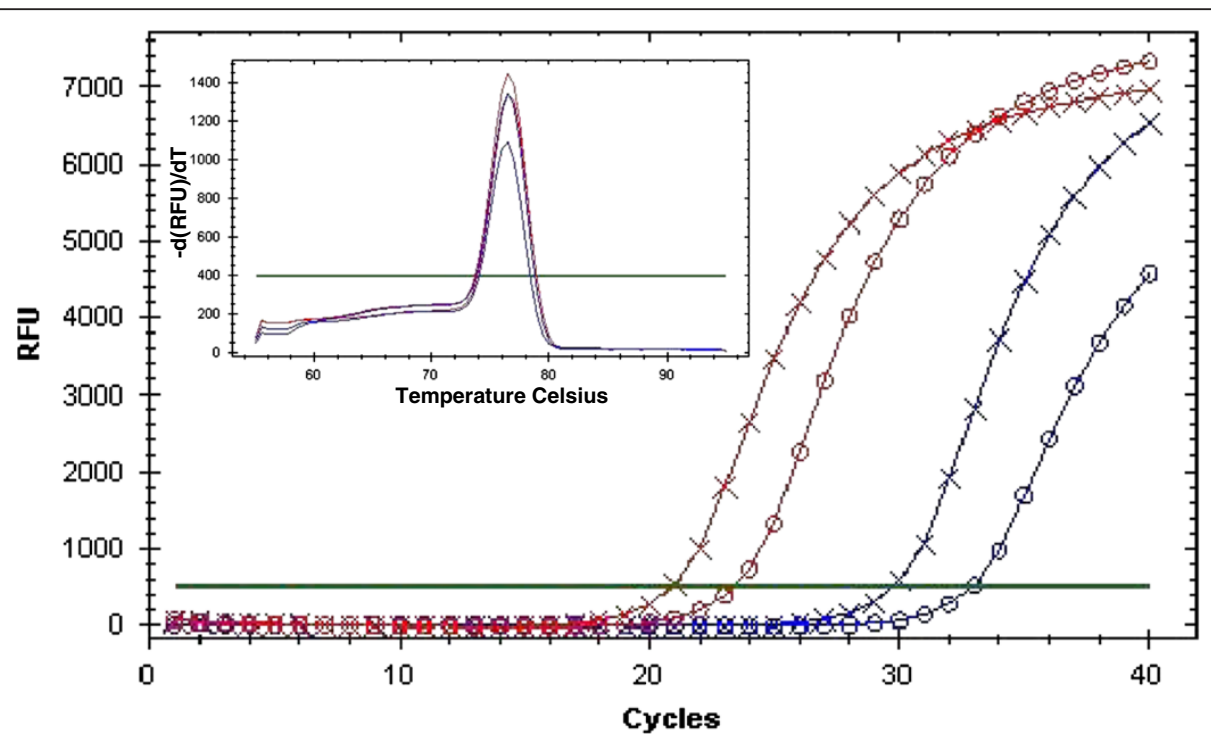

Figure 1 Amplification and melting curves of LDR real-time PCR (qPCR): impact of the heating step: Blood samples with $1 \mathrm{mf}$ (blue curves) and with $100 \mathrm{mf}$ (red curves) were tested, The number of reaction cycles needed to detect a signal was lower when the lysate had been heated at $100^{\circ} \mathrm{C}$ before DNA purification (cross curves) than without this heating step (circle curves). The melt peak temperature was the same for each sample $=76.5^{\circ} \mathrm{C}$. 


\section{Real-time PCR}

qPCR assays were performed on the Bio-Rad real-time thermal cycler CFX96, using the $W b$-LDR primers [17] and the SYBR Green fluorescence dye with melting curve analysis. The target sequence size is $90 \mathrm{bp}$ long. Each reaction contained $12.5 \mu$ of IQ SYBRGreen supermix $2 \times$ (Biorad), $0.75 \mu \mathrm{l}$ of $10 \mathrm{pmol}^{-1} \mathrm{l}^{-1}$ of forward and reverse primers and $5 \mu \mathrm{l}$ of DNA template in a total volume of $25 \mu \mathrm{l}$. Thermal cycling conditions for PCR were $95^{\circ} \mathrm{C}$ for 3 minutes followed by 40 cycles of $10 \mathrm{~s}$ at $95^{\circ} \mathrm{C}$ and $30 \mathrm{~s}$ at $60^{\circ} \mathrm{C}$. The melt curve analysis was performed by reducing the temperature to $55^{\circ} \mathrm{C}$ for $1 \mathrm{mi}$ nute and then raising the temperature by increments of $0.5^{\circ} \mathrm{C}$ every $10 \mathrm{~s}$ up to $95^{\circ} \mathrm{C}$. The results were analysed with the CFX manager software to calculate the $\mathrm{Ct}$ value corresponding to the number of reaction cycles necessary to detect a signal above baseline.

\section{Assays and results}

Before performing the assays with pool samples, the impact of the heat treatment prior to the DNA purification was assessed for each individual sample. To that end, lysates were heated at $100^{\circ} \mathrm{C}$ for 5 minutes then cooled immediately on ice. DNA purification and qPCR were then performed as described above. The lysates from either 0 $\mathrm{mf}, 1 \mathrm{mf}$ or $100 \mathrm{mf}$ blood samples were tested in duplicate.

An amplicon of the expected 90 bp size as estimated by electrophoresis was produced from all samples containing $\mathrm{mf}$, with a melt peak temperature of $76.5^{\circ} \mathrm{C}$. No amplification was observed for negative samples. For both $\mathrm{mf}$ concentrations, the PCR amplification signal was detected earlier in samples that had undergone the heating treatment (Figure 1). We concluded that the heating step improved the outcome of DNA amplification and decided to include this step before DNA purification in all subsequent assays.

Furthermore, we verified that qPCR sensitivity was maintained when processing only a fraction of the lysate. For that purpose, blood samples spiked with one $\mathrm{mf}$ and samples having $\approx 100 \mathrm{mf}$ were used. For both $\mathrm{mf}$ concentrations, two volumes of lysate were processed: either the whole lysate $(600 \mu \mathrm{l})$ as described previously [2] or one sixth of the lysate $(100 \mu \mathrm{l})$. Seven blood samples spiked with one $\mathrm{mf}$ were processed, 3 with the whole lysate and 4

Table 1 qPCR results depending on lysate volume processed and on microfilaria (mf) burden

\begin{tabular}{cccccc}
\hline $\begin{array}{c}\text { mf per } \\
\text { sample }\end{array}$ & $\begin{array}{c}\text { Volume of } \\
\text { lysate }(\boldsymbol{\mu l})\end{array}$ & $\begin{array}{c}\text { Sample } \\
\text { replicates }\end{array}$ & $\begin{array}{c}\mathbf{C t} \\
\text { mean }\end{array}$ & $\begin{array}{c}\mathbf{C t} \\
\text { range }\end{array}$ & Tm \\
\hline 1 & 600 & 3 & 29.8 & {$[28.6-31.9]$} & 76.5 \\
& 100 & 4 & 31.9 & {$[31.0-33.1]$} & 76.5 \\
\multirow{2}{*}{100} & 600 & 2 & 21.6 & {$[21.5-21.6]$} & 76.5 \\
& 100 & 2 & 23.6 & {$[23.5-23.7]$} & 76.5 \\
\hline
\end{tabular}

Table 2 Ct values depending on lysate volume and lysate number per pool

\begin{tabular}{cccccc}
\hline $\begin{array}{c}\text { Sample } \\
\text { volume }(\boldsymbol{\mu l})\end{array}$ & $\begin{array}{c}\text { Pool } \\
\text { size }\end{array}$ & $\begin{array}{c}\text { Pools } \\
\text { processed }\end{array}$ & Ct mean & Range & Tm \\
\hline 100 & 1 & 4 & 31.9 & {$[31-33.1]$} & 76.5 \\
& 5 & 4 & 31.4 & {$[30.3-32.2]$} & 76.5 \\
& 10 & 4 & 31.9 & {$[31.1-32.9]$} & 76.5 \\
& 12 & 4 & 32.3 & {$[31.2-33.7]$} & 76.5 \\
50 & 10 & 3 & 33.3 & {$[32.7-33.7]$} & 76.5 \\
& 12 & 1 & 33.6 & & 76.5 \\
\hline
\end{tabular}

using only $100 \mu \mathrm{l}$ of lysate. Negative blood samples and $100 \mathrm{mf}$ blood samples were analysed in duplicate. Details of samples analysed and average $\mathrm{Ct}$ values are reported in Table 1. No PCR amplification was detected for the negative samples. The signal obtained from $100 \mu \mathrm{l}$ of lysate compared to that from the whole lysate was weaker due to the reduced quantity of DNA processed. Nevertheless, positive amplification using one sixth of $1 \mathrm{mf}$ blood lysate was systematically obtained (average $\mathrm{Ct}$ value of 31.9 cycles), showing no loss of sensitivity.

Finally, taking those results into account, we combined $100 \mu \mathrm{l}$ of individual lysates in pools of increasing sizes, with the objective of detecting a single $\mathrm{mf}$ positive sample diluted in at least 11 negative samples. The pools were prepared by mixing the lysate of a single $\mathrm{mf}$ positive sample with the lysates of 0 to 11 negative blood samples. DNA of mixes was purified and the qPCR performed as described above. Four pools were made and tested for each pool size and the mean $\mathrm{Ct}$ values are reported in Table 2 . These values obtained ranged between 31.4 and 32.3 thus showing limited variability. We concluded that diluting the $W b$ target DNA in increasing amounts of human DNA did not prevent its amplification. This demonstrates that using the improved qPCR assay allows detection of a single $\mathrm{mf}$ from a $60 \mu \mathrm{l}$ dried blood spot (equivalent to a burden of $18 \mathrm{mf} / \mathrm{ml}$ ) diluted

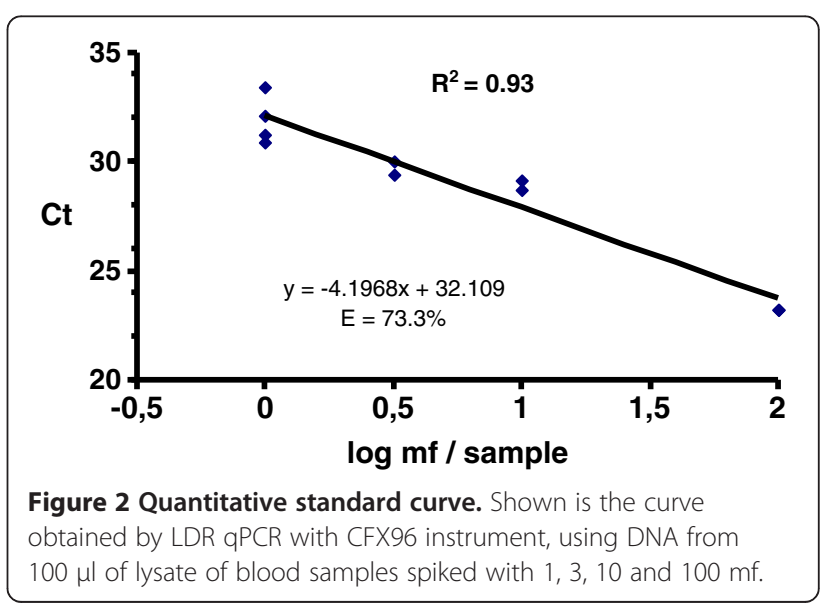


in a pool of at least 12 samples. Further analyses of large sample size were not tested.

The experiment was repeated using only $50 \mu \mathrm{l}$ of lysate per sample to save time by reducing the number of centrifugations necessary during the DNA purification step. We have processed three pools of 10 lysates and one pool of 12 lysates, and obtained mean Ct values of 33.3 and 33.6 respectively (Table 2 ). The results showed that as little as $50 \mu \mathrm{l}$ of lysate could be used to constitute the pools without loss of sensitivity.

Using the Ct values obtained with all low positive and negative samples tested, an arbitrary threshold was set at a Ct value of 36 (threshold baseline at 500) to exclude false positive results. All results with a $\mathrm{Ct}$ value below 36 and a melt peak temperature of $76.5^{\circ} \mathrm{C}$ were therefore considered positive.

$\mathrm{Wb}$ PCR assays are not currently reported as quantitative. We generated a standard curve using $100 \mu \mathrm{l}$ of lysate from blood samples with 1, 3, 10 or $100 \mathrm{mf}$ to be able to quantify the qPCR results (Figure 2). There was a linear relationship between the log number of $\mathrm{mf}$ spiked and the number of reaction cycles needed to detect signal above baseline. Using this method, $100 \mu \mathrm{l}$ of each individual lysate contained in an LF positive pool can be tested retrospectively and the $\mathrm{mf}$ concentration(s) of infected individuals estimated using the standard curve. This additional information could be helpful for program managers to estimate the risk of transmission, as the number of $\mathrm{mf}$ ingested by mosquito vector increases as the density of $\mathrm{mf}$ in blood increases.

\section{Conclusion}

One of the principal measures of success of the GPELF is the decrease in microfilaremia prevalence and in $\mathrm{mf}$ load, a sine qua non condition to LF elimination. Our improvement of the PCR-based pool screening method allows for a highly sensitive screening tool relevant for LF control. Although this assay currently requires real-time PCR equipment, it may ultimately be adapted for use in resource-poor endemic areas [28]. The present assay may stimulate the development and support of much-needed national and regional reference laboratories to suit the various LF epidemiological situations and populations at risk.

\section{Competing interests}

The authors declare having no competing interests.

\section{Authors' contributions}

$\mathrm{CP}$ conceived and designed the experiments. CP performed the experiments and analyzed the data. CP and AL wrote the paper. Both authors read and approved the final manuscript.

\section{Acknowledgements}

We would like to thank Tokahi Rotillon for her help and technical assistance We are thankful to Dr. Bossin for his critical contribution to this manuscript. We gratefully acknowledge Dr Sandra J. Laney for her critical reading of the manuscript.
Received: 9 December 2012 Accepted: 14 April 2013

Published: 18 April 2013

\section{References}

1. Ottesen EA, Hooper PJ, Bradley M, Biswas G: The global programme to eliminate lymphatic filariasis: health impact after 8 years. PLoS Negl Trop Dis 2008, 2(10):e317.

2. Gass K, de Rochars MV B, Boakye D, Bradley M, Fischer PU, Gyapong J, Itoh M, Ituaso-Conway N, Joseph H, Kyelem D, et al: A multicenter evaluation of diagnostic tools to define endpoints for programs to eliminate bancroftian filariasis. PLoS Negl Trop Dis 2012, 6(1):e1479.

3. WHO: Global Programme to Eliminate Lymphatic Filariasis. Monitoring and epidemiological assessment of mass drug administration: a manual for national elimination programmes. Geneva: World Health Organization; 2011. WHO/HTM/NTD/PCT/2011.4.

4. Schuetz A, Addiss DG, Eberhard ML, Lammie PJ: Evaluation of the whole blood filariasis ICT test for short-term monitoring after antifilarial treatment. Am J Trop Med Hyg 2000, 62(4):502-503.

5. Tisch DJ, Bockarie MJ, Dimber Z, Kiniboro B, Tarongka N, Hazlett FE, Kastens W, Alpers MP, Kazura JW: Mass drug administration trial to eliminate lymphatic filariasis in Papua New Guinea: changes in microfilaremia, filarial antigen, and Bm14 antibody after cessation. Am J Trop Med Hyg 2008, 78(2):289-293.

6. Simonsen PE, Pedersen EM, Rwegoshora RT, Malecela MN, Derua YA, Magesa SM: Lymphatic filariasis control in Tanzania: effect of repeated mass drug administration with ivermectin and albendazole on infection and transmission. PLoS Negl Trop Dis 2010, 4(6):e696.

7. Molyneux DH: Filaria control and elimination: diagnostic, monitoring and surveillance needs. Trans R Soc Trop Med Hyg 2009, 103(4):338-341.

8. Weil GJ, Ramzy RM: Diagnostic tools for filariasis elimination programs. Trends Parasitol 2007, 23(2):78-82.

9. Ramzy RM, El Setouhy M, Helmy H, Ahmed ES, Abd Elaziz KM, Farid HA, Shannon WD, Weil GJ: Effect of yearly mass drug administration with diethylcarbamazine and albendazole on bancroftian filariasis in Egypt: a comprehensive assessment. Lancet 2006, 367(9515):992-999.

10. Wamae CN, Njenga SM, Ngugi BM, Mbui J, Njaanake HK: Evaluation of effectiveness of diethylcarbamazine/albendazole combination in reduction of Wuchereria bancrofti infection using multiple infection parameters. Acta Trop 2011, 120(Suppl 1):S33-38.

11. Boyd A, Won KY, McClintock SK, Donovan CV, Laney SJ, Williams SA, Pilotte N, Streit TG, de Rochars MV B, Lammie PJ: A community-based study of factors associated with continuing transmission of lymphatic filariasis in Leogane, Haiti. PLoS Negl Trop Dis 2010, 4(3):e640.

12. Mathieu E, Dorkenoo A, Otogbe FK, Budge PJ, Sodahlon YK: A laboratorybased surveillance system for Wuchereria bancrofti in Togo: a practical model for resource-poor settings. Am J Trop Med Hyg 2011, 84(6):988-993.

13. Iboh Cl, Okon OE, Opara KN, Asor JE, Etim SE: Lymphatic filariasis among the Yakurr people of Cross River State. Nigeria. Parasit Vectors 2012, 5:203.

14. Koroma JB, Bangura MM, Hodges MH, Bah MS, Zhang Y, Bockarie MJ: Lymphatic filariasis mapping by immunochromatographic test cards and baseline microfilaria survey prior to mass drug administration in Sierra Leone. Parasit Vectors 2012, 5:10.

15. Esterre P, Plichart C, Sechan Y, Nguyen NL: The impact of 34 years of massive DEC chemotherapy on Wuchereria bancrofti infection and transmission: the Maupiti cohort. Tropical medicine \& international health: TM \& IH 2001, 6(3):190-195.

16. Zhong M, McCarthy J, Bierwert L, Lizotte-Waniewski M, Chanteau S, Nutman $T B$, Ottesen EA, Williams SA: A polymerase chain reaction assay for detection of the parasite Wuchereria bancrofti in human blood samples. Am J Trop Med Hyg 1996, 54(4):357-363.

17. Rao RU, Atkinson L, Ramzy RM, Helmy H, Farid HA, Bockarie MJ, Susapu M, Laney SJ, Williams SA, Weil GJ: A real-time PCR-based assay for detection of Wuchereria bancrofti DNA in blood and mosquitoes. Am J Trop Med Hyg 2006, 74(5):826-832.

18. Williams SA, Nicolas L, Lizotte-Waniewski M, Plichart C, Luquiaud P, Nguyen $L N$, Moulia-Pelat JP: A polymerase chain reaction assay for the detection of Wuchereria bancrofti in blood samples from French Polynesia. Trans $R$ Soc Trop Med Hyg 1996, 90(4):384-387.

19. McCarthy JS, Zhong M, Gopinath R, Ottesen EA, Williams SA, Nutman TB: Evaluation of a polymerase chain reaction-based assay for diagnosis of Wuchereria bancrofti infection. J Infect Dis 1996, 173(6):1510-1514. 
20. Fischer $P$, Boakye $D$, Hamburger J: Polymerase chain reaction-based detection of lymphatic filariasis. Medical microbiology and immunology 2003, 192(1):3-7.

21. Williams SA, Laney SJ, Bierwert LA, Saunders $\sqcup$, Boakye DA, Fischer P, Goodman D, Helmy H, Hoti SL, Vasuki V, et al: Development and standardization of a rapid, PCR-based method for the detection of Wuchereria bancrofti in mosquitoes, for xenomonitoring the human prevalence of bancroftian filariasis. Ann Trop Med Parasitol 2002, 96(Suppl 2):S41-46.

22. Plichart C, Sechan Y, Davies N, Legrand AM: PCR and dissection as tools to monitor filarial infection of Aedes polynesiensis mosquitoes in French Polynesia. Filaria journal 2006, 5:2.

23. Plichart C, Laney SJ, Sechan Y, Davies N, Legrand AM: Correction PCR and dissection as tools to monitor filarial infection of Aedes polynesiensis mosquitoes in French Polynesia. Filaria journal 2007, 6:5.

24. Boakye DA, Baidoo HA, Glah E, Brown C, Appawu M, Wilson MD: Monitoring lymphatic filariasis interventions: Adult mosquito sampling, and improved PCR - based pool screening method for Wuchereria bancrofti infection in Anopheles mosquitoes. Filaria journal 2007, 6:13.

25. Farid HA, Morsy ZS, Helmy H, Ramzy RM, El Setouhy M, Weil GJ: A critical appraisal of molecular xenomonitoring as a tool for assessing progress toward elimination of Lymphatic Filariasis. Am J Trop Med Hyg 2007, 77(4):593-600.

26. Supali T, Ismid IS, Wibowo H, Djuardi Y, Majawati E, Ginanjar P, Fischer P: Estimation of the prevalence of lymphatic filariasis by a pool screen PCR assay using blood spots collected on filter paper. Trans $R$ Soc Trop Med Hyg 2006, 100(8):753-759.

27. Ramzy RM, Farid HA, Kamal IH, Ibrahim GH, Morsy ZS, Faris R, Weil GJ, Williams SA, Gad AM: A polymerase chain reaction-based assay for detection of Wuchereria bancrofti in human blood and Culex pipiens. Trans R Soc Trop Med Hyg 1997, 91(2):156-160.

28. Fink DL, Kamgno J, Nutman TB: Rapid molecular assays for specific detection and quantitation of Loa loa microfilaremia. PLoS Negl Trop Dis 2011, 5(8):e1299.

doi:10.1186/1756-3305-6-110

Cite this article as: Plichart and Lemoine: Monitoring and evaluation of lymphatic filariasis interventions: an improved PCR-based pool screening method for high throughput Wuchereria bancrofti detection using dried blood spots. Parasites \& Vectors 2013 6:110.

\section{Submit your next manuscript to BioMed Central and take full advantage of:}

- Convenient online submission

- Thorough peer review

- No space constraints or color figure charges

- Immediate publication on acceptance

- Inclusion in PubMed, CAS, Scopus and Google Scholar

- Research which is freely available for redistribution 